\title{
Saving land to feed a growing population: consequences for consumption of crop and livestock products
}

\author{
Heleen R. J. Van Kernebeek ${ }^{1}$ - Simon J. Oosting ${ }^{1}$ - Martin K. Van Ittersum ${ }^{2}$. \\ Paul Bikker ${ }^{3}$ Imke J. M. De Boer ${ }^{1}$
}

Received: 16 December 2014 / Accepted: 16 June 2015 / Published online: 15 July 2015

(C) The Author(s) 2015. This article is published with open access at Springerlink.com

\begin{abstract}
Purpose The expected increase in demand for food raises concerns about the expansion of agricultural land worldwide. To avoid expansion, we need to focus on increasing land productivity, reducing waste, and shifting human diets. Studies exploring diet shifts so far have ignored competition for land between humans and animals. Our objective was to study the relation between land use, the share of animal protein in the human diet, population size, and land availability and quality. Methods We used linear programming to determine minimum land required to feed a population a diet with $0-80 \%$ of the protein derived from terrestrial domestic animals. Populations ranged from 15 million to the maximum number of people that could be supported by the system. The agricultural system in the Netherlands was used as illustration, assuming no import and export of feed and food. Daily energy and protein requirements of humans were fulfilled by a diet potentially consisting of grain (wheat), root and tuber crops (potato, sugar beet), oil crops (rapeseed), legumes (brown bean), and animal
\end{abstract}

Responsible editor: Thomas Jan Nemecek

Electronic supplementary material The online version of this article (doi:10.1007/s11367-015-0923-6) contains supplementary material, which is available to authorized users.

Heleen R. J. Van Kernebeek

Heleen.vankernebeek@outlook.com

1 Animal Production Systems Group, Wageningen University, P.O. Box 338, 6700 AH Wageningen, The Netherlands

2 Plant Production Systems group, Wageningen University, Wageningen, The Netherlands

3 Livestock Research, Wageningen University and Research Centre, Wageningen, The Netherlands protein from ruminants (milk and meat) and monogastrics (pork).

Results and discussion Land is used most efficiently if people would derive $12 \%$ of dietary protein from animals (\% PA), especially milk. The role of animals in such a diet is to convert co-products from crop production and the human food industry into protein-rich milk and meat. Below $12 \% \mathrm{PA}$, humaninedible products were wasted (i.e., not used for food production), whereas above $12 \% \mathrm{PA}$, additional crops had to be cultivated to feed livestock. Large populations (40 million or more) could be sustained only if animal protein was consumed. This results from the fact that at high population sizes, land unsuitable for crop production was necessary to meet dietary requirements of the population, and contributed to food production by providing animal protein without competing for land with crops.

Conclusions A land use optimization model including crop and animal production enables identification of the optimal $\%$ PA in the diet. Land use per capita was lowest at $12 \%$ PA. At this level, animals optimally consume co-products from food production. Larger populations, furthermore, can be sustained only with diets relatively high in \% PA, as land unsuitable for crop production is needed to fulfil their food demand. The optimal \% PA in the human diet depended on population size and the relative share of land unsuitable for crop production.

Keywords Animal production - Competition for resources . Crop production $\cdot$ Human diets $\cdot$ Land use $\cdot$ Optimization

\section{Introduction}

Global food demand is projected to increase by $60 \%$ by 2050 (Alexandratos and Bruinsma 2012), because of a growing 
world population and increasing wealth. This increased demand for food has raised concerns about environmental impacts related to expansion of agricultural land worldwide (Foley et al. 2011). Pressure on land increases not only because of future food demands but also because of land degradation (Stringer 2008) and increasing demands for biofuels (OECD/FAO 2014), biomaterials, housing, and infrastructure.

Currently, agriculture already occupies about $38 \%$ of the terrestrial surface of the Earth, divided among 1.5 billion ha of cropland and 3.4 billion ha of pastures (Alexandratos and Bruinsma 2012). Meeting the food demand projected for 2050 may require an additional 0.2 to 1 billion ha of land under agriculture (Tilman et al. 2011). This additional land will include land of relatively low fertility and productivity and will be partly located in currently forested or protected areas (Alexandratos and Bruinsma 2012; Foley et al. 2011; Ramankutty et al. 2002). Converting such forested lands to agricultural land conflicts with the need for nature preservation (Royal Society of London 2009; Smith et al. 2010; World Bank 2007) and leads to adverse environmental effects (DeFries et al. 2004; Gerber et al. 2013; Millennium Ecosystem Assessment 2005; Pielke et al. 2002).

There is considerable agreement, therefore, that humans should minimize further expansion of agricultural land. Limiting global land expansion for food production, however, requires a combination of interventions on the production and consumption side (Foley et al. 2011). Proposed strategies include increasing yields on underperforming lands (Van Ittersum et al. 2013), reducing waste (Papargyropoulou et al. 2014), and shifting human diets (Stehfest et al. 2009; Wirsenius et al. 2010).

Studies exploring the potential contribution of dietary shifts generally conclude that (i) a vegan diet requires the least land (Hallström et al. 2015) and (ii) that land use decreases when ruminant meat is replaced by monogastric meat (Stehfest et al. 2009; Wirsenius et al. 2010). These studies, however, do not consider the competition between humans and animals for land. Animals fed with cereals, for example, directly compete with humans for land. No matter how efficiently produced, direct consumption of cereals by humans is ecologically more efficient than consumption of animal-source food produced by animals fed with these cereals (Foley et al. 2011; Godfrey et al. 2010). Compared to pigs or poultry, ruminants generally consume less feed that can be consumed directly by humans (De Vries and De Boer 2010; Vellinga et al. 2009). Ruminants, however, can still compete with humans for land, as some of the world's grasslands are also suitable for production of arable crops (Suttie et al. 2005). To limit global land use for food production, therefore, we should consume livestock products from systems that use land that is unsuitable or less suitable for crop production and/or that use co-products from food production (Van Zanten et al. 2015). The objective of this study, therefore, was to identify which factors influence the relation between land use, the share of animal protein in the human diet, population size, and land availability and quality. We determined the minimum amount of land used to feed a growing population a diet varying in the percentage of the protein derived from terrestrial domestic animals. The agricultural system in the Netherlands was used as case-study, assuming no import and export of feed and food.

\section{Material and methods}

This study was based on a land use optimization model created in General Algebraic Modelling System (GAMS) version 24.2 .

\subsection{System definition}

The system in our case study consisted of production, processing, and consumption of food in the Netherlands as a standalone system (Fig. 1). The objective of this system was to produce human-edible energy and protein for domestic use. The model estimated the land area required to feed populations ranging from 15 million (close to the current population size) to the maximum number of people that could be supported by the system. Within this range, we increased population size by steps of five million people. As we approached the maximum number of people, we increased population size with steps of 0.1 million people. Daily per capita requirements were defined as $2000 \mathrm{kcal}$ and $57 \mathrm{~g}$ protein (EFSA 2009; EFSA 2012). Total sugar intake was limited to the maximum recommended intake level of $90 \mathrm{~g}$ per capita per day (EFSA 2009). We estimated land use for human diets varying in the percentage of the protein derived from terrestrial domestic animals ("protein derived from animals" or PA) between $0 \%$ PA (a vegan diet) to $80 \%$ PA. Within this range, we increased $\%$ PA by steps of $5 \%$ (and by steps of $1 \%$ where relevant). Land use was determined for cultivation of crops and forages.

\subsection{Crop production system}

The current Dutch agricultural area of $1842 \times 10^{3}$ ha (CBS 2013) represented the maximum available area for production of crops and forages. This area consists of clay soils $(839 \times$ $\left.10^{3} \mathrm{ha}\right)$, sandy soils $\left(779 \times 10^{3} \mathrm{ha}\right)$, and peat soils $(224 \times$ $10^{3}$ ha) (Lesschen et al. 2012). Clay and sandy soils can be used for cultivation of crops and forages, whereas peat soils were assumed to be suitable only for cultivation of grass, since most of these are too wet for competitive crop production. For the fact that they are marginal for crop production, peat soils represent so-called marginal lands in this study.

Crops included in the modeling represented the following major groups: grains, root and tuber crops, oil crops, and 


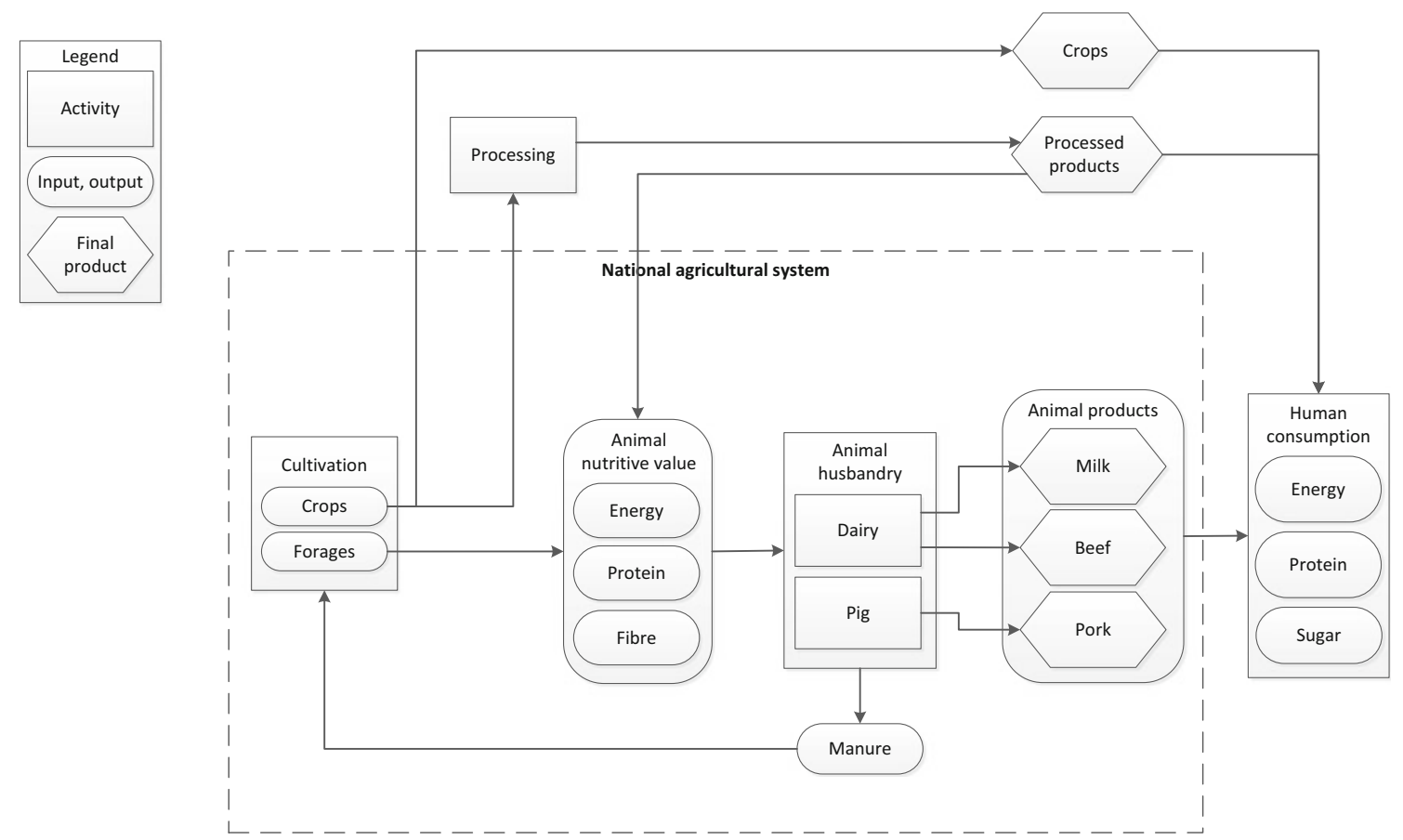

Fig. 1 Diagram of the system

legumes (Electronic Supplementary Material I). In each food crop group, the arable crop with the largest cultivated area in the Netherlands was chosen (LEI and CBS 2012). Grains were represented by wheat, root, and tuber crops by potatoes and sugar beets, oil crops by rapeseed, and legumes by brown beans. Seven crop rotations were adopted from Van Ittersum et al. (1995), the length of rotations varying from 1 to 6 years (Electronic Supplementary Material I). Crop yields were based on current Dutch averages. To compute the annual yield of each crop within a rotation, we multiplied the crop's yield with its frequency in the rotation (i.e., years of cultivation in a rotation divided by total years of rotation). In the harvested crop, we distinguished the main crop product and humaninedible products (i.e., wheat straw, sugar beet tops and tails, and rapeseed straw). Wheat and maize stubble, potato haulms, sugar beet leaves, and bean straw were left on the field as source of soil organic carbon. We lowered actual yield levels by $7 \%$ for potatoes, $5 \%$ for beans, and $2 \%$ for wheat and rapeseed to account for production of seeds and seedlings (PPO 2009; PPO 2012). Hence, seed and seedling production was already accounted for in crop yields in our calculations $\left(Y_{i, j, t}\right)$. In addition to crops, we considered production of maize silage and grass as forage for dairy cattle. We assumed no effects on yields of climatic differences across the Netherlands (Van Wart et al. 2013).

To determine total dry matter production (ton DM) of harvested product $j\left(Q_{j}\right)$, we multiplied the land area allocated to crop rotation $i$ on land type $l\left(X_{i, l}\right)$ by the fresh matter yield of harvested product $j$ from the same crop rotation and land type $\left(Y_{i, j, l}\right)$, and by the dry matter content of harvested product $j$
$\left(\mathrm{DM}_{j}\right)$, then summed across rotations $(i=1,7)$ and land types $(l=1,3$; Eq. (1)).

$Q_{j}=\sum_{i=1}^{7} \sum_{l=1}^{3} X_{i, l} \times Y_{i, j, l} \times D M_{j}$

\subsection{Processing of crops}

Harvested products (e.g., rapeseed) were divided into food and feed products (e.g., oil and meal) following ratios of dry matter output and dry matter input of various processing steps (Electronic Supplementary Material II). These dry matter output/input ratios were calculated from fresh matter output/ input ratios (Mattsson et al. 2001; Vellinga et al. 2013) and dry matter contents of food (RIVM 2013) and feed products (PDV 2011). To determine dry matter production of food or feed product $k\left(Q_{k}\right)$, we multiplied production quantities of harvested product $j$ assigned to process $m\left(Q_{j, m}\right)$ with the output/input ratio of product $k$ produced from harvested product $j$ in process $m\left(C_{j, m, k}\right)$ (Eq. (2)). Processes that do not divide one product into multiple products (e.g., ensiling of grass and heating of beans) were assigned an output/input ratio of 1 .

$Q_{k}=Q_{j, m} \times C_{j, m, k}$

We converted production quantities of human-edible products into available energy, protein and sugar, using nutrient contents of products found in the Dutch nutrient database NEVO (RIVM 2013). Similarly, for animal feeds (see 
Sect. 2.4), we converted production quantities into nutrients using feed tables (PDV 2011).

\subsection{Animal production system}

We included two animal production systems with contrasting abilities to use marginal land. We chose pig production as representative for monogastrics, a system that derives its feeds from land suitable for cultivation of crops, and dairy production as representative for ruminants, able to use marginal land. We chose these systems as within the group of monogastrics and ruminants, pork and dairy products are the largest contributors to protein in the human diet (PPE/PVV 2013; RIVM 2011).

Production levels of animals were based on Dutch averages. We modeled pig and dairy production based on animal production units (PUs) per animal place per year. One pig PU consisted of 3.3 fattening pigs, 0.12 sows, and 0.07 gilts (Electronic Supplementary Material III). One pig PU produced $171 \mathrm{~kg}$ pork per year, which corresponds to $1475 \mathrm{MJ}$ and $55 \mathrm{~kg}$ human-edible protein per year. Net energy requirements per pig PU (equivalent to the weighted sum of net energy requirements (PDV 2012) for fattening pigs, sows and gilts) totaled $9901 \mathrm{MJ}$ per year (Electronic Supplementary Material IV). The diet of one pig PU had a minimum of $16 \%$ and a maximum of $18 \%$ crude protein (Bikker 2014; Devendra and Clyde Parris 1970) and a digestibility coefficient of at least $80 \%$ (Bikker 2014). Grass, maize silage, straw, sugar beet tops and tails, and sugar factory lime were excluded from consumption by pigs (Bikker 2014). We applied additional restrictions to create a plausible diet (Electronic Supplementary Material V).

One cow PU consisted of a dairy cow and its replacement stock, i.e., 0.31 heifers aged $1-2$ years, and 0.34 calves aged 0-1 year (Electronic Supplementary Material VI). Surplus calves were excluded from our analysis. One cow PU produced $8502 \mathrm{~kg}$ fat-and-protein-corrected-milk and $74 \mathrm{~kg}$ meat per year, both derived only from the milking cow, corresponding to $22,775 \mathrm{MJ}, 303 \mathrm{~kg}$ human-edible protein and $383 \mathrm{~kg}$ total sugar per year (Electronic Supplementary Material VI). Net energy requirements for one cow PU (equivalent to the weighted sum of net energy requirements (PDV 2012) for the milking cow, replacement heifer, and calf) totaled 51,977 MJ and $606 \mathrm{~kg}$ intestinal digestible protein per year (Electronic Supplementary Material VII and VIII). Rumen degradable protein balance had a lower limit of 0 and an upper limit of $200 \mathrm{~g}$ per cow per day (Dijkstra 2014). To assure sufficient structure in the diet, the structure value of the diet (PDV 2012) was at least 1 per $\mathrm{kg}$ DM. Maximum feed intake capacity was limited to 14.9 saturation values per day for dairy cows, 3.2 for replacement heifers, and 5.9 for replacement calves (PDV 2012). Sugar factory lime was excluded from consumption by cows. We applied additional restrictions to create a plausible diet (Electronic Supplementary Material V).

\subsection{Manure production and application}

Nutrient (i.e., nitrogen and phosphorus) excretion by animals was computed as the difference between nutrient intake and nutrients retained in animals and their products. Nutrient intake was computed based on information about feed intake and nutrient content of feed ingredients (PDV 2011). Nutrient retention in growing pigs was computed from nutrient concentrations in body tissue (Groenestein et al. 2008) and production data (Electronic Supplementary Material III), and totaled $9.4 \mathrm{~kg} \mathrm{~N}$ and $2.0 \mathrm{~kg}$ P per pig PU per year. Nutrient retention in milk and body tissue of culled cows and growing young stock was computed from nutrient concentrations in body tissue and milk (RVO 2010) and production data (Electronic Supplementary Material VI), and totaled $50.1 \mathrm{~kg}$ $\mathrm{N}$ and $9.64 \mathrm{~kg} P$ per cow PU per year.

In line with European Union (EU) legislation, application of manure to crop and grassland was limited to $170 \mathrm{~kg}$ nitrogen from animal manure per hectare per year (RVO 2014). Additionally, we restricted total nitrogen application from manure and artificial fertilizer to the sum of crop- and soil-typespecific maximum nitrogen application rates allowed by EU legislation. The nitrogen fertilizer replacement value of manure was set at $60 \%$ (RVO 2014). Moreover, we restricted total phosphate application to the sum of soil-type-specific maximum phosphate application rates for grass and arable land (RVO 2014). These rates depended on the phosphate levels of the soil, as determined by Schoumans (2007).

\subsection{Losses}

We accounted for losses of food crop products, meat, and milk by applying loss fractions (Gustavsson et al. 2011) during postharvest handling, storage, processing, packing, distribution, and consumption. We assumed that at most $21 \%$ of total food crop product losses could potentially be used as feed (Soethoudt and Timmermans 2013). We assumed $5 \%$ postharvest handling and storage losses for wheat straw, sugar beet tops and tails, and rapeseed straw. In addition, we accounted for conservation and feeding losses for crop products allocated to animals. We assumed conservation losses of $4 \%$ for moist concentrates, $5-10 \%$ for potato peel, silage maize, and beans, $15-17.5 \%$ for grass silage and potatoes, $20 \%$ for straw, and $25 \%$ for sugar beet tops and tails (Remmelink et al. 2012). Feeding losses were $2 \%$ for dried concentrates, $3 \%$ for moist concentrates, and $5 \%$ for roughages (Remmelink et al. 2012). No losses were assigned to fresh grass, as fresh grass yields represented net production (i.e., intake) by animals. 
Table 1 Characteristics of the reference situation and, assessed in sensitivity analyses, alternative situations

\begin{tabular}{lll}
\hline Sensitivity & Reference situation & Alternative situations \\
\hline Soil type & $12 \%$ peat soils, $46 \%$ clay soils, $42 \%$ sandy soils & $\begin{array}{l}\text { A: } 5 \% \text { peat soils, } 50 \% \text { clay soils, } 45 \% \text { sandy soils } \\
\text { Yield }\end{array}$ \\
Meat content & Average Dutch yields under current practices & $\begin{array}{r}20 \% \text { peat soils, } 30 \% \text { clay soils, } 30 \% \text { sandy soils } \\
\text { peat soils compared to the reference situation }\end{array}$ \\
\hline
\end{tabular}

\subsection{Objective function}

The linear-programming model allocated crop products to humans or animals based on an objective function to minimize land use for all crop rotations $i$ on all land types $l\left(X_{i, j}\right)$ (Eq. (3)) while meeting energy and protein requirements of the human population.

$$
\operatorname{Min} \sum_{i=1}^{7} \sum_{l=1}^{3} X_{i, l}
$$

\subsection{Sensitivity analysis}

We explored the impact of changes in the share of different soil types, in crop and forage yields and in the share of protein from meat in the animal protein consumed on final results of land use and human dietary composition (Table 1)

Changes in share of different soil types In the reference situation, land consisted of $46 \%$ clay soils, $42 \%$ sandy soils, and $12 \%$ peat soils. To determine the impact of decreasing the share of marginal land (peat soil), we studied a situation in which land consisted of $50 \%$ clay soils, $45 \%$ sandy soils, and $5 \%$ peat soils (less peat). To determine the impact of increasing the share of marginal land, we studied a situation in which land consisted of $30 \%$ clay soils, $30 \%$ sandy soils, and $40 \%$ peat soils (more peat).Changes in crop and grass yields To determine the impact of differences in relative productivity of clay, sand, and peat soils, we decreased yields on sandy soils by $20 \%$ and on peat soils by $50 \%$.

Changes in meat content of the diet In the reference situation, we did not set requirements for meat consumption. One possible outcome, therefore, was that PA could come mainly from milk. To determine the impact of meat consumption, we forced meat (pork and/or beef) to constitute at least $50 \%$ of PA, as this is the current situation in the Netherlands (RIVM 2009).

\section{Results}

\subsection{Land use}

\subsubsection{Reference situation}

The relation between the minimum amount of land needed to feed a specific population and the percentage of the protein derived from animals (\% PA) in the diet was nonlinear (Fig. 2). As \% PA increased, land use initially decreased up to about $12 \% \mathrm{PA}$, and subsequently increased. Diets with about $12 \%$ PA, therefore, systematically had the lowest land use. Furthermore, as population size increased, the possible range of $\% \mathrm{PA}$ in the diet became more narrow. This implies that larger populations could not be supported by a vegan diet or a diet containing a high \% PA.

The amount of land needed per capita increased as population size increased (Table 2). Per capita land use increased with population size because high yielding soils, i.e., clay soils, were cultivated first, followed by sandy soils (Fig. 3). This order follows from the generally higher yields at rotation level on clay soils than on

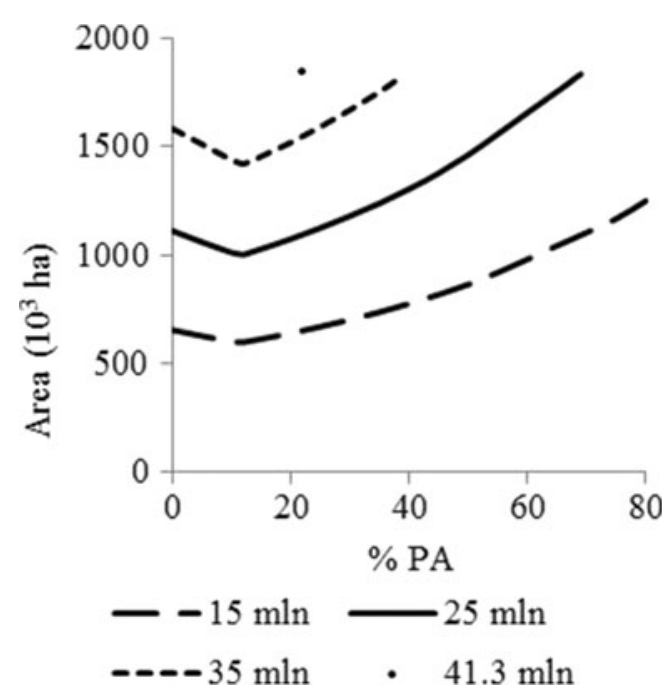

Fig. 2 Minimum land $\left(10^{3}\right.$ ha) needed for feeding the total population with diets varying in percentage of dietary protein from animals $(\% \mathrm{PA})$ in the reference situation. $m \ln$ million 
Table 2 Per capita land use index for diets varying in percentage of dietary protein from animals (\% PA) and various populations in the reference situation

\begin{tabular}{lllll}
\hline \multicolumn{5}{l}{ Population (mln) } \\
\cline { 2 - 5 }$\%$ PA & 15 & 25 & 35 & 40 \\
\hline 0 & 100 & 102 & 104 & \\
10 & 92 & 93 & 94 & \\
15 & 94 & 94 & 95 & 96 \\
20 & 98 & 99 & 100 & 100 \\
30 & 107 & 108 & 109 & \\
40 & 119 & 120 & & \\
50 & 132 & 134 & & \\
60 & 150 & 152 & & \\
70 & 169 & & & \\
80 & 191 & & & \\
\hline
\end{tabular}

Index $=100$ for a diets with $0 \% \mathrm{PA}$ and a population of 15 million people $m \ln$ million

sandy soils. As population size increased, therefore, the relative contribution of lower yielding soils increased, explaining the increase in per capita land use (Table 2 and Fig. 3).

Food production on clay soils was sufficient to feed a population of 15 million people a diet with $0-25 \%$ PA. In the range from 30 to $60 \% \mathrm{PA}$, in addition to clay soils, sandy soils were used for the production of silage maize, as silage maize had higher yields on sandy soils than on clay soils. If PA exceeded $60 \%$, sandy soils were predominantly used for the production of crops, as all clay soils were fully used. Feeding a population of 35 million, however, required all clay soils and most of the sandy soils, even at low \% PA. From $15 \%$ PA upward, in addition to clay and sandy soils, peat soils were used to produce grass (see Electronic Supplementary Material X for diet composition per cow PU). Diets with more than $39 \%$ PA were not feasible.

Fig. 3 Land use ( $\mathrm{m}^{2} /$ capita) per soil type for diets varying in percentage of dietary protein from animals $(\% \mathrm{PA})$ and populations of 15 million (left) and 35 million (right) people in the reference situation. For a population of 35 million people, $39 \%$ PA was the last feasible option. $m \ln$ million

\subsubsection{Impact of changes in share of different soil types}

Decreasing the share of peat soils (i.e., from $12 \%$ in the reference situation to $5 \%$ ) increased the maximum number of people that could be fed from the land, whereas increasing the share of peat soils (i.e., from $12 \%$ in the reference situation to $40 \%$ ) decreased the maximum number of people that could be fed from the land (Fig. 4). This difference in the number of people that can be fed can be explained by the higher productivity of clay and sandy soils than peat soils. Furthermore, in the situation with a smaller share of peat soils, the maximum number of people (i.e., 43.6 million) consumed diets with about $15 \%$ PA, whereas in the situation with a larger share of peat soils, the maximum number of people (i.e., 31.5 million) consumed diets with about $44 \%$ PA. In other words, when population size increases in a region with a larger share of marginal land, this population can be supported only if a relatively high percentage of its protein comes from animal sources. Moreover, a vegan diet is only feasible for smaller populations in such a situation, i.e., larger populations can only be sustained when animal protein is consumed. The feasible share of animal protein in the human diet, therefore, depends on the population size in combination with the share of marginal land.

\subsubsection{Impact of changes in crop and grass yields}

Decreasing crop yields on sandy and peat soils did not increase per capita land use compared to the reference situation as long as \% PA was less than $30 \%$, because only clay soils were used in that range to feed a population of 15 million in both the reference and alternative situation (Fig. 5). When \% PA was $30 \%$ or more, per capita land use increased relatively quickly compared to the reference situation (Fig. 3), because of the lower availability of highly productive land.

We expected decreasing crop yields on sandy soils to result in higher land use on these soils compared to the reference

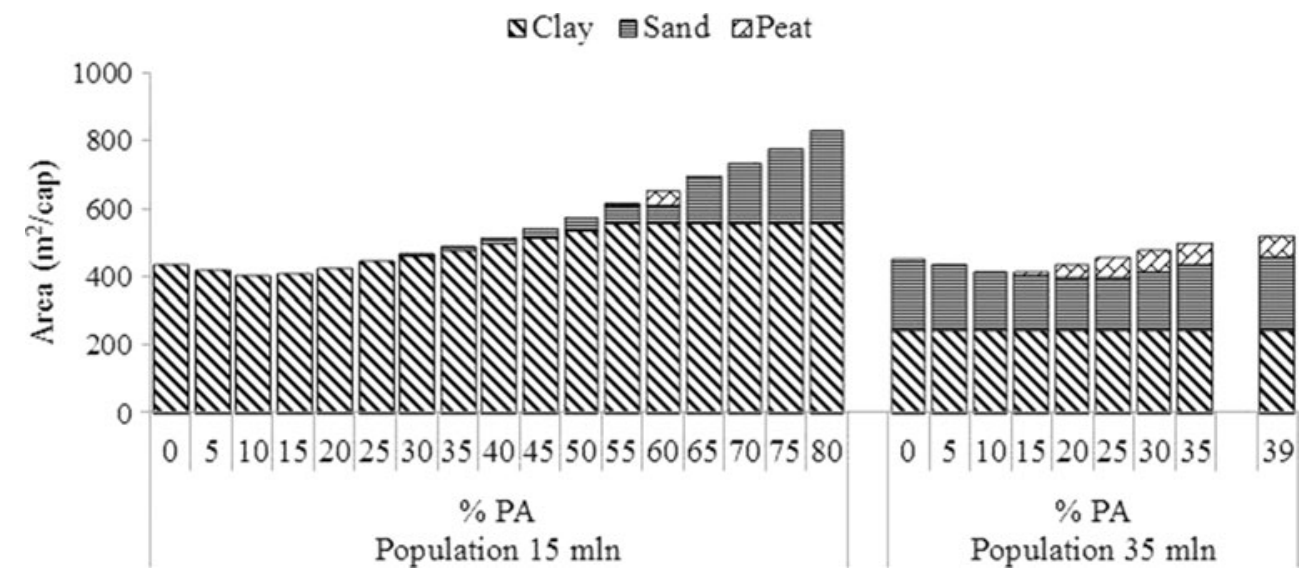


Fig. 4 Minimum land $\left(10^{3}\right.$ ha) needed for feeding the total population with diets varying in percentage of dietary protein from animals (\% PA) in alternative situations with $5 \%$ (left) and $40 \%$ (right) of total land area underlain by peat soils. $m \ln$ million
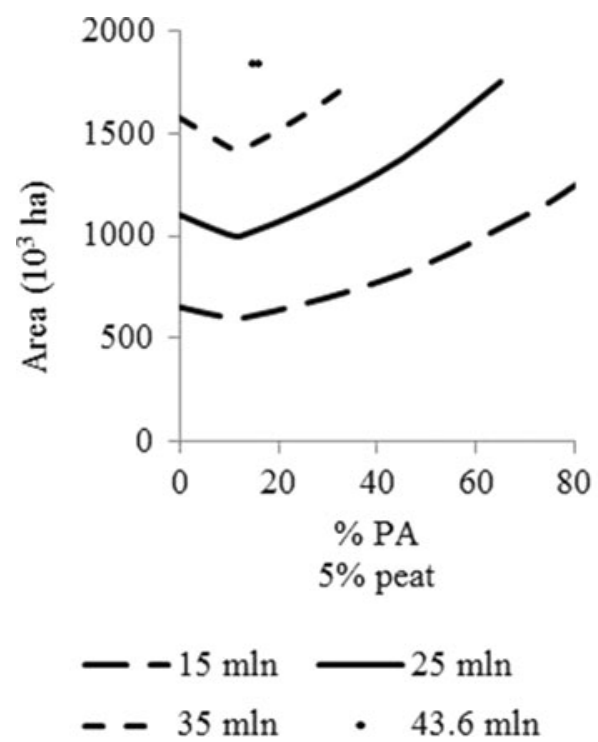

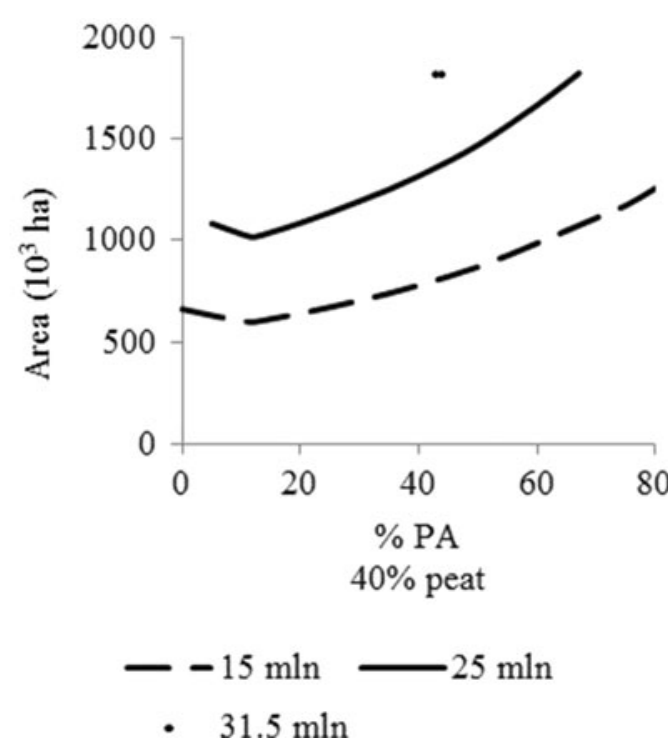

situation, under high population pressure or high \% PA. For a population of 15 million, this was indeed the case for diets with $50 \%$ PA and more (Fig. 5). For diets containing less than $50 \%$ PA, however, sandy soils were not used in the alternative situation. This resulted from the relatively small difference in yield of maize silage between clay and sandy soils in the reference situation. After reducing yields by $20 \%$ on sandy soils, yield of maize silage was higher on clay soils, which postponed the use of sandy soils to a higher $\%$ PA.

To feed 35 million people, more sandy soils were used then in the reference situation, due to their lower yields. From $20 \%$ PA upward, sandy soils were fully used and peat soils were needed to produce animal protein. The maximum feasible \% PA for this population was lower than that in the reference situation.

\subsection{Consumption of animal protein}

\subsubsection{Reference situation}

When \% PA was less than $10 \%$, daily protein intake per capita equaled the recommended intake level of $57 \mathrm{~g}$, but this recommended level was often exceeded when \% PA exceeded $10 \%$ (Fig. 6) (see Electronic Supplementary Material IX for human diet composition). Our simulations also show that animal protein was mainly provided by milk (fixed ratio of protein from milk and beef of 14:1) (Fig. 6), which is due to higher protein productivity of dairy cows than of pigs (De Vries and de Boer 2010).

\subsubsection{Impact of changes in meat content of the diet}

When requiring that at least $50 \%$ of the dietary protein of a population of 15 million came from meat (in our model, beef or pork), the percentage of dietary protein from pork gradually increased from about $2 \%$ (i.e., $\mathrm{PA}=5 \%$ ) to about $37 \%(\mathrm{PA}=$ $80 \%$ ) (Fig. 7), at the expense of dietary protein from milk in particular. Land use in this alternative scenario, therefore, is slightly higher than that in the reference scenario. Hence, replacing dietary protein from milk with that from meat implies that we can eat less protein derived from animals. For a population of 35 million people, maximum \% PA in the diet decreased to $35 \%$ (Fig. 7), compared to $39 \%$ in the reference
Fig. 5 Land use ( $\mathrm{m}^{2} /$ capita) per soil type for diets varying in percentage of dietary protein from animals ( $\%$ PA) and populations of 15 million (left) and 35 million (right) people in the alternative situation with $20 \%$ lower yields on sandy soils and $50 \%$ lower yields on peat soils compared to the reference situation. For a population of 35 million people, $23 \%$ PA was the last feasible option. $m \ln$ million

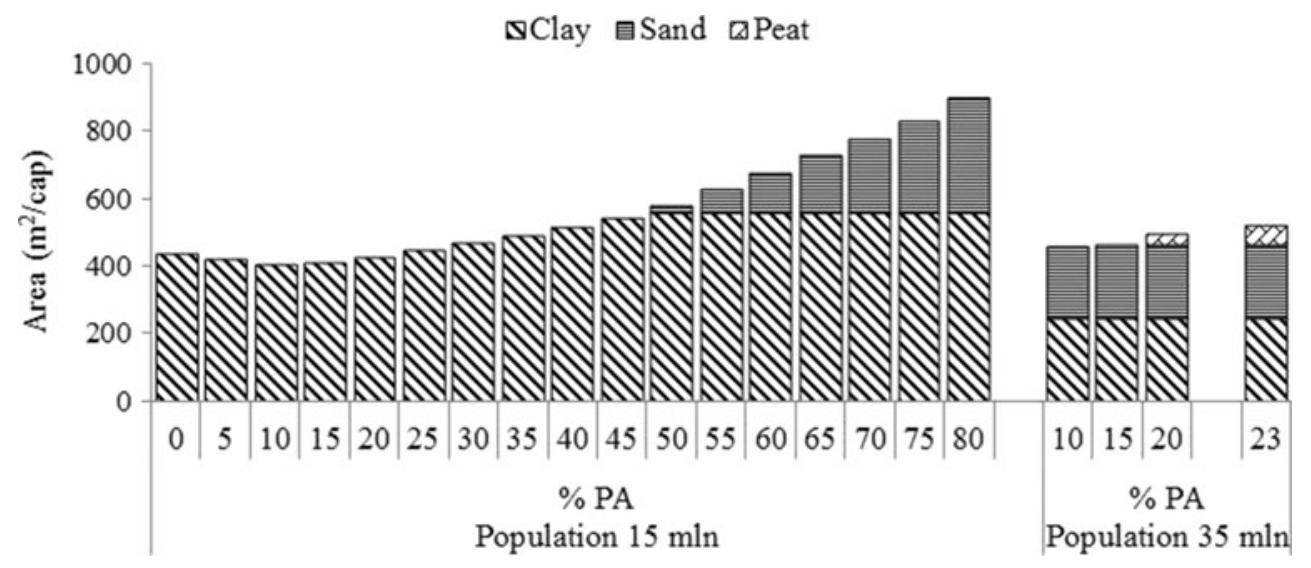


Fig. 6 Per capita protein intake (g/day) from crops, milk, beef, and pork for diets varying in percentage of dietary protein from animals (\% PA) and populations of 15 million (left) and 35 million (right) people in the reference situation. For a population of 35 million people, $39 \%$ AP was the last feasible option. The horizontal line indicates the daily protein requirement of $57 \mathrm{~g} / \mathrm{cap}$. $m \ln$ million

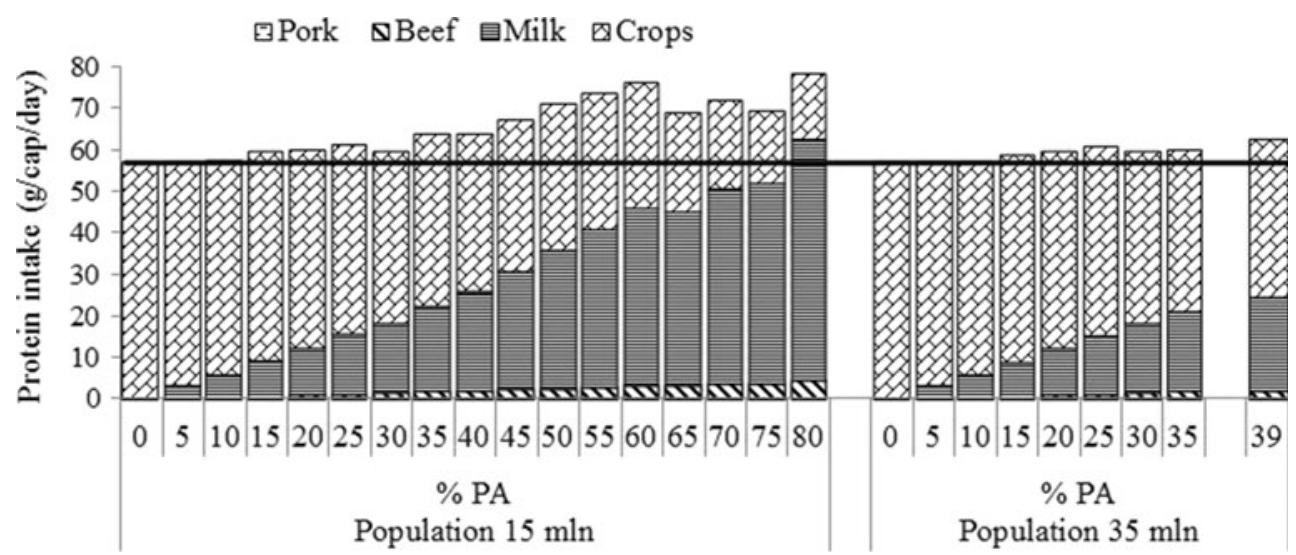

situation (Fig. 6) (see Electronic Supplementary Material XI for diet composition per pig PU).

\section{Discussion and conclusions}

Our model provides insights into relations between land use, the share of animal protein in the human diet, population size, and land availability and quality. We demonstrated that at lower population sizes, consumption of about $12 \%$ of dietary protein from animal source foods resulted in the most efficient use of agricultural land. In the range from 0 to $20 \% \mathrm{PA}$, land use remains more or less stable, whereas beyond $20 \%$ PA land use increases more strongly. At the highest population size that could be supported by the land, however, the optimal percentage of dietary protein derived from animal source foods ranged from 15 to $45 \%$.

Minimizing land use resulted in per capita land use of 400$800 \mathrm{~m}^{2} /$ year, values lower than actual land use values reported by Meier and Christen (2013), Terluin et al. (2013), and Van
Oorschot et al. (2012). This implies that humans can use land more efficiently if they would accept austere diets. Diets resulting from our analysis consisted of a limited variety of products because we used proxies for the five major groups of crop production, and for monogastric and ruminant production. We think, however, that including a wider variety of plant-based or terrestrial domestic animal-based products would not have affected our conclusions. Products from fisheries were not considered, as these systems do not use land.

In our results, animal protein in the human diet consisted mainly of milk, and beef was consumed as a co-product of milk production (milk/beef ratio of 14:1). When requiring that at least $50 \%$ of the animal protein consumed should come from meat, pork was added to the human diet. Let us consider, however, what would have happened had we included beef production from suckler beef systems. Suckler cows can exploit marginal lands by producing beef via grazing. Beef from suckler cows, however, would have been included in the human diet only if we had defined minimum requirements for beef consumption, or if marginal lands had been suitable only

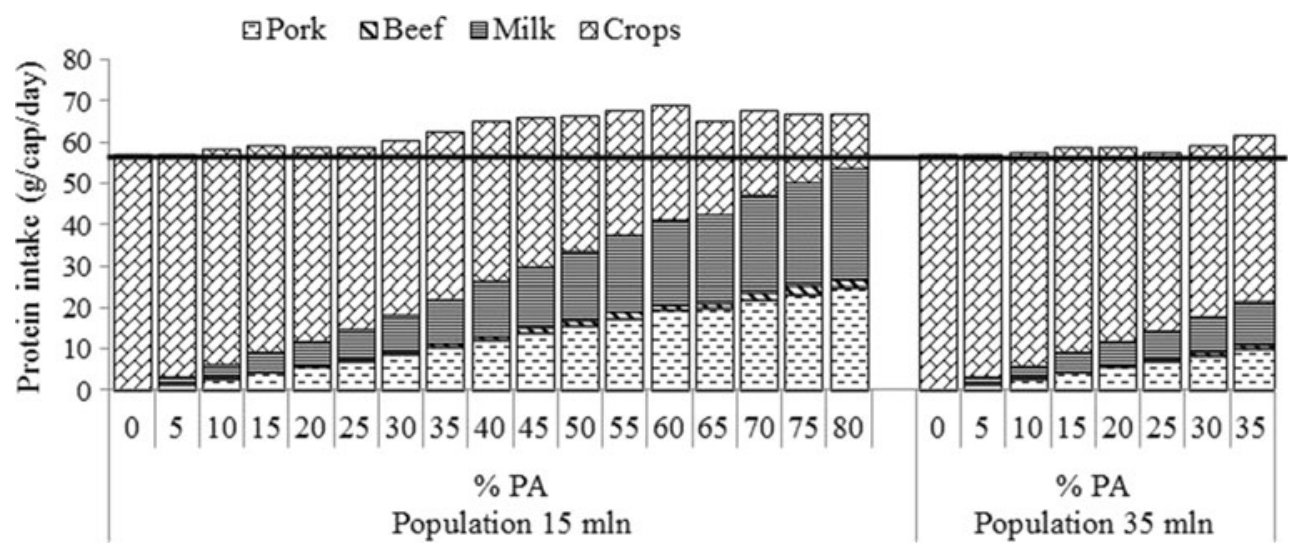

Fig. 7 Per capita protein intake (g/day) from crops, milk, beef, and pork for diets varying in percentage of dietary protein from animals (\% PA) and populations of 15 million (left) and 35 million (right) people in the alternative situation in which meat contributed at least $50 \%$ of PA. For

a population of 35 million people, $35 \%$ PA was the last feasible option. The horizontal line indicates the daily protein requirement of $57 \mathrm{~g} / \mathrm{cap}$. mln million 
for grazing of suckler cows. This is because from a land use perspective grazing of dairy cows is preferred to grazing of suckler cows because dairy cows produce animal protein more efficiently (De Vries and De Boer 2010). Furthermore, feed produced on clay or sandy soil is converted more efficiently to animal protein by pigs than by beef cattle. We realize, however, that producing beef or mutton on marginal lands unsuitable for grazing of dairy cattle can be of utmost importance in other areas, and this will result in an increase of per capita land use.

Another important finding of our study is that a vegan diet always required more land than a diet with small amounts of animal protein. In other words, land is used most efficiently if people consume small amounts of animal protein, which is also referred to as the "default livestock diet" (Fairlie 2010). The role of animals in a default livestock diet is to convert coproducts from arable production (e.g., straw) and the human food industry (e.g., beet pulp) that cannot be consumed directly by humans into protein-rich milk and meat. When no animal protein is produced, as suits a vegan diet, these humaninedible products are wasted (i.e., not used for food production) or used as a bio-energy source, and additional crops will have to be cultivated to meet nutritional energy and protein requirements of the population. Consequently, larger populations could not be supported by a vegan diet and a population cannot exceed a certain size unless animal protein is consumed.

Larger populations also could not be supported by a diet with a high percentage of protein derived from animal source foods. A population of 35 million people, for example, could not be supported from a diet containing $40 \%$ PA or more. When demand for animal protein exceeds the default livestock diet, additional crops will have to be cultivated, resulting in higher land use. At higher population sizes this land is not available, which limits consumption of high amounts of animal protein, and, thus, the possible percentages of dietary protein derived from animal-source foods decreased. Moreover, at the highest population size that could be supported by the land, the optimal percentage of dietary protein derived from animal source food ranged from 15 to $45 \%$, the exact value depending on assumed crop yields and the share of marginal land. Peat soils, although relatively productive in the Netherlands, were considered marginal land as they are suitable only for grass production. Also, peat soils are somewhat less productive than clay soils in the Netherlands. Thus, increasing the share of peat soils increased the optimal percentage of dietary protein from animal source foods at the highest population size, but at the same time decreased the maximum number of people that could be fed. In contrast, decreasing the relative share of peat soils, and hence increasing the relative share of arable soils, would increase the number of people that could be fed and lower the optimal percentage of dietary protein from animal source foods at higher population sizes. The optimal percentage of dietary protein from animals in future diets, therefore, depends on the share of marginal land in the world, together with the productivity of these marginal lands (which is atypically high in the Netherlands). Moreover, the optimal percentage of dietary protein from animals also depends on the type of crops and the extent to which co-products are harvested. A higher availability of co-products for feed would shift optimum land use to higher \% PA but also reduce carbon inputs to the soil.

A final important conclusion is that our results contradict results of life cycle assessment (LCA) studies that explored land use of diets differing in the percentage of protein derived from animals. These LCA studies suggest that vegan diets require the least amount of land, followed by vegetarian diets (Hallström et al. 2015; Meier and Christen 2013). Optimization, as employed in our study, accounts for the unsuitability of marginal lands to grow crops, the suitability of animals to use human-inedible products, and the coproduction of meat and milk. These aspects are not included in LCA studies, and explain the different results. Our land-use optimization model could be extended to the use of other limited resources such as fossil energy and phosphorous, and the emission of, for example, greenhouse gases.

Acknowledgments We thank Marcel Lubbers, Bert Rijk (Plant Production Systems Group, Wageningen University) and Jantine van Middelkoop (Wageningen UR Livestock Research) for their contributions to the land use model, crop production data, and livestock data, respectively, and Mike Grossman for language editing.

Open Access This article is distributed under the terms of the Creative Commons Attribution 4.0 International License (http:// creativecommons.org/licenses/by/4.0/), which permits unrestricted use, distribution, and reproduction in any medium, provided you give appropriate credit to the original author(s) and the source, provide a link to the Creative Commons license, and indicate if changes were made.

\section{References}

Alexandratos N, Bruinsma J (2012) World agriculture towards 2030/2050: the 2012 revision. ESA Working paper No. 12-03. FAO, Rome

Bikker P (2014) Wageningen UR Livestock Research. Personal communication, Wageningen

CBS (2013) Statistics Netherlands (Centraal Bureau voor de Statistiek). http://statline.cbs.nl/statweb/

De Vries M, De Boer IJM (2010) Comparing environmental impacts for livestock products: a review of life cycle assessments. Livest Sci 128:1-11

DeFries RS, Foley JA, Asner GP (2004) Land-use choices: balancing human needs and ecosystem function. Front Ecol Environ 2:249257

Devendra C, Clyde Parris EC (1970) Optimum crude protein levels for growing and finishing pigs in a tropical environment. Trop Anim Health Pro 2:162-166 
Dijkstra J (2014) Personal communication. Animal Sciences. Wageningen University, Wageningen

EFSA (2009) Scientific Opinion of the Panel on Dietetic products, Nutrition and Allergies on a request from European Commission on the review of labelling reference intake values for selected nutritional elements. EFSA Journal 1008:1-14

EFSA (2012) EFSA Panel on Dietetic Products, Nutrition and Allergies (NDA); Scientific Opinion on Dietary. Reference Values for protein. EFSA Journal 10:2557

Fairlie S (2010) Meat: a benign extravagance. Hyden House, Petersfield Foley JA et al (2011) Solutions for a cultivated planet. Nature 478:337342

Gerber PJ, Steinfeld H, Henderson B, Mottet A, Opio C, Dijkman J, Falcucci A, Tempio G (2013) Tackling climate change through livestock - a global assessment of emissions and mitigation opportunities. Food and Agriculture Organization of the United Nations, Rome

Godfrey HCJ et al (2010) Food security: the challenge of feeding 9 billion people. Science 327:812-818

Groenestein CM, Van Bruggen C, Hoeksma P, Jongbloed AW, Velthof GL (2008) Nadere beschouwing van stalbalansen en gasvormige stikstofverliezen uit de intensieve veehouderij. Wageningen University and Research Center, Wageningen

Gustavsson J, Cederberg C, Sonesson U, van Otterdijk R, Meybeck A (2011) Global food losses and food waste. Extend, causes and prevention. Food and Agriculture Organization of the United Nations, Rome

Hallström E, Carlsson-Kanyama A, Börjesson P (2015) Environmental impact of dietary change: a systematic review. J Cleaner Prod 91:1-11

LEI and CBS (2012) Land- en tuinbouwcijfers 2012 [Agricultural and horticultural figures]. Landbouw Economisch Instituut (LEI), The Hague

Lesschen JP, Heesmans H, Mol-Dijkstra J, van Doorn A, Verkaik E, van den Wyngaert I, Kuikman P (2012) Mogelijkheden voor koolstofvastlegging in de Nederlandse landbouw en natuur. Alterra Wageningen UR, Wageningen

Mattsson B, Wallén E, Blom A, Stadig M (2001) Livscykelanalys av matpotatis (Life cycle assessement of potatoes). SIK - The Swedish Institution for Food and Biotechnology. As cited by Gustavsson J, Cederberg C, Sonesson U, van Otterdijk R, Meybeck A 2011: Global food losses and food waste. Extend, causes and prevention, Food and Agriculture Organization of the United Nations, Rome, Italy

Meier T, Christen O (2013) Environmental impacts of dietary recommendations and dietary styles: Germany as an example. Environ Sci Technol 47:877-888

Millennium Ecosystem Assessment (2005) Ecosystems and Human Well-being: Synthesis

OECD/FAO (2014) Biofuels, in OECD-FAO Agricultural Outlook 2014. OECD Publishing

Papargyropoulou E, Lozano RK, Steinberger J, Wright N, Ujang ZB (2014) The food waste hierarchy as a framework for the management of food surplus and food waste. J Cleaner Prod 76:106-115

PDV (2011) CVB Veevoedertabel 2011. Chemische samenstellingen en nutritionele waarden van voedermiddelen. Product board for animal feed, The Hague

PDV (2012) Tabellenboek Veevoeding 2012. Product Board Animal Feed, The Hague

Pielke RA Sr et al (2002) The influence of land-use change and landscape dynamics on the climate system: relevance to climate-change policy beyond the radiative effect of greenhouse gases. Philos T Roy Soc A 360:1705-1719

PPE/PVV (2013) Cattle, meat and eggs in the Netherlands. Indicators 2012 (Vee, Vlees en Eieren in Nederland Kengetallen 2012). Zoetermeer, the Netherlands (in Dutch)

PPO (2009) Kwantitatieve Informatie Akkerbouw en Vollegrondsgroenteteelt 2009. Praktijkonderzoek Plant \&
Omgeving B.V. Businessunit Akkerbouw, Groene ruimte en Vollegrondsgroenten. Wageniningen UR, The Netherlands

PPO (2012) Kwantitatieve Informatie Akkerbouw en Vollegrondsgroenteteelt 2012. Praktijkonderzoek Plant en Omgeving. Stichting Dienst Landbouwkundig Onderzoek, Wageningen UR

Ramankutty N, Foley JA, Norman J, McSweeney K (2002) The global distribution of cultivable lands: current patterns and sensitivity to possible climate change. Global Ecol Biogeogr 11:377-392

Remmelink GJ, Blanken K, Middelkoop JCV, Ouweltjes W, Wemmenhove H (2012) Handboek Melkveehouderij 2012. Wageningen UR Livestock Research, Lelystad

RIVM (2009) Consumptiepeiling, Jongvolwassenen, consumptie productgroepen, bronnen van macronutriënten. Rijkinstituut voor Volksgezondheid en Milieu. Ministerie van Volksgezondheid Welzijn en Sport

RIVM (2011) Contribution (weight \%) of food products to the intake of energy and macronutrients for people in the age of 19-30 years. Young adults, consumption of product groups and sources of macronutrients. (Bijdrage (gewogen \%) van voedingsmiddelen aan de inneming van energie en macronutriënten voor 19-30-jarigen. Jongvolwassenen, consumptie productgroepen, bronnen van macronutriënten). In Dutch. . National Institute for Public Health and the Environment, the Netherlands, www.voedselconsumptiepeiling.nl (Version 11-2009)

RIVM (2013) NEVO Table 2013. National Institute for Public Health and the Environment, The Netherlands

Royal Society of London (2009) Reaping the benefits: science and the sustainable intensification of global agriculture. London

RVO (2010) Guidance farm-specific excretion of dairy (Handreiking bedrijfsspecifieke excretie melkvee. Versie per 1 januari 2010 van kracht)

RVO (2014) Tabellen Mestbeleid 2014-2017. State Agency for enterprising Netherlands (Rijksdienst voor Ondernemend Nederland)

Schoumans OF (2007) Trends in de fosfaattoestand van landbouwgronden in Nederland in de periode 1998-2003. Alterra, part of Wageningen University and Research Center, Wageningen

Smith P et al (2010) Competition for land. Philos T Roy Soc B 365:29412957

Soethoudt H, Timmermans T (2013) Monitor food waste (Monitor voedselverspililng). Mid-term report. . Wageningen UR Food \& Biobased Research, Wageningen, the Netherlands

Stehfest E, Bouwman L, van Vuuren DP, den Elzen MGJ, Eickhout B, Kabat P (2009) Climate benefits of changing diet. Climate Change 95:83-102

Stringer L (2008) Can the UN Convention to Combat Desertification guide sustainable use of the world's soils? Front Ecol Environ 6: 138-144

Suttie JM, Reynolds SG, Battello C (2005) Grasslands of the world. FAO, Rome

Terluin IJ, Kamphuis BM, Oudendag DA, Van Leeuwen MGA (2013) Voedselvoorziening in Nederland onder buitengewone crisisomstandigheden. LEI, Social Economics Research Institute, Wageningen

Tilman D, Balzer C, Hill J, Befort BL (2011) Global food demand and the sustainable intensification of agriculture. Proc Natl Acad Sci 108: 20260-20264

Van Ittersum MK, Hijmans RJ, Scheele D (1995) escription and user guide of GOAL-QUASI: an IMGLP model for the exploration of future land use vol 2. Research Institute for Agrobiology and Soil Fertility. The C.T. de Wit Graduate School for Production Ecology, Wageningen

Van Ittersum MK, Cassman KG, Grassini P, Wolf J, Tittonell P, Hochman Z (2013) Yield gap analysis with local to global relevance - a review. Field Crop Res 143:4-17 
Van Oorschot M, Rood T, Vixseboxse E, Wilting H, Van der Esch S (2012) De Nederlandse voetafdruk op de wereld: hoe groot en hoe diep? Planbureau voor de Leefomgeving (PBL), Den Haag

Van Wart J et al (2013) Use of agro-climatic zones to upscale simulated crop yield potential. Field Crop Res 143:44-55

Van Zanten HHE, Mollenhorst H, Klootwijk CW, Van Middelaar CE, De Boer IJM (2015) Global food security: land use efficiency of livestock systems. Int J of Life Cycle Assess (in press)

Vellinga TV, Van Laar H, Thomasse MA, De Boer IJM, Berkhout P, Aiking $H$ (2009) Environmental impact of animal feed (Milieueffecten van diervoeders). Report 205. Animal Sciences
Group, Wageningen University and research centre, Lelystad, The Netherlands

Vellinga TV, Blonk H, Marinussen M, Van Zeist WJ, De Boer IJM, Starmans D (2013) Methodology used in FeedPrint: a tool quantifying greenhouse gas emissions of feed production and utilization. Wageningen UR Livestock Research, Lelystad

Wirsenius S, Azar C, Berndes G (2010) How much land is needed for global food production under scenarios of dietary changes and livestock productivity increases in 2030? Agr Syst 103:621-638

World Bank (2007) World Development Report 2008: Agriculture for development. Washington DC 